\title{
Tingkat Pengetahuan Reproduksi dan Kondisi Fertilitas Generasi Milenial di Desa Kerik Kabupaten Magetan
}

\author{
Intan Cristia Ega Pratiwi, Indah Rahmadianti, Faliq Dzyi Nuha, Wachidatul Linda \\ Yuhanna*
}

\section{(C) 2021 JEMS (Jurnal Edukasi Matematika dan Sains)}

This is an open access article under the CC-BY-SA license

(https:/ / creativecommons.org/licenses/by-sa/4.0/) ISSN 2337-9049 (print), ISSN 2502-4671 (online)

\begin{abstract}
Abstrak:
Pengetahuan serta pemahaman kesehatan reproduksi serta fertilitas sangatlah dibutuhkan bagi generasi milenial untuk mempersiapkan pernikahan mereka. Tujuan dari penelitian ini adalah mengetahui pengetahuan dan kondisi fertilitas generasi milenial di Desa Kerik Kabupaten Magetan. Penelitian ini telah di lakukan pada bulan Juni 2021 di Desa Kerik. Penelitian ini adalah penelitian kuantitatif dengan metode survey. Populasi sejumlah 145, sampel sebanyak 45 . Pengambilan sampel dilakukan secara purposive. Hasil yang diperoleh adalah tingkat pengetahuan reproduksi dari generasi milenial di Desa Kerik menunjukkan bahwa 31 responden sebagian besar memiliki pengetahuan kriteria sangat baik sebanyak $68,90 \%$ dan 14 responden yang memiliki pengetahuan kriteria baik sebanyak 31,10\%. Data diperoleh bahwa 45 responden sudah menikah dan tidak pernah bercerai. Kondisi mengandung, perempuan di Desa Kerik yang sudah pernah mengandung sebanyak $71 \%$ dan $29 \%$ belum pernah mengandung. Kondisi melahirkan istri di Desa Kerik diperoleh data perempuan melahirkan bayinya secara sesar sebanyak 49\%. Usia melahirkan pertama di bawah usia kurang dari 20 tahun sebanyak 16\%, melahirkan di usia 20-25 tahun sebanyak 47\%. Kondisi anak yang dilahirkan dengan selamat dan sehat sebanyak 100\%, sedangkan pada saat bayi dilahirkan tidak ada angka kematian bayi setelah dilahirkan. Istri mengandung lagi setelah melahirkan anak pertama sebanyak 9\%. Di desa Kerik yang memiliki satu anak sebanyak $51 \%$, yang memiliki lebih dari satu anak sebanyak $18 \%$, sedangkan yang berencana memiliki anak lagi sebanyak 47\%. Kondisi istri yang menggunakan alat kontrasepsi sebanyak 24\%, istri yang sering menggunakan alat kontrasepsi sebanyak 13\%, sedangkan istri yang rutin memeriksakan pemakaian alat kontrasepsi sebanyak $16 \%$.
\end{abstract}

Kata Kunci : Reproduksi, Fertilitas, Generasi Milenial

\section{Abstract:}

Knowledge and understanding of reproductive health and fertility are needed for millennials to prepare for their marriage. The purpose of this study was to determine the knowledge and fertility conditions of the millennial generation in Kerik Village, Magetan Regency. This research was conducted in June 2021 in Kerik Village. This research is quantitative research with survey method. The population is 145 , the sample is 45 . The sampling was done purposively. The results obtained are the level of reproductive knowledge of the millennial generation in Kerik Village, which shows that most of the 31 respondents have very good knowledge of criteria as much as $68.90 \%$ and 14 respondents who have good knowledge of criteria as much as $31.10 \%$. The data obtained that 45 respondents were married and never divorced. Conditions of pregnancy, women in Kerik Village who have been pregnant are $71 \%$ and $29 \%$ have never been pregnant. In the condition of giving birth to a wife in Kerik Village, $49 \%$ of women gave birth to their babies by cesarean section. The age of first giving birth under the age of less than 20 years is $16 \%$, giving birth at the age of $20-25$ years is $47 \%$. The condition of children born safely and healthy is $100 \%$, while at the time the baby is born there is no infant mortality rate after birth. Wives are pregnant again after giving birth to their first child as much as $9 \%$. In Kerik village, $51 \%$ have one child, $18 \%$ have more than one child, while those who plan to have another child are $47 \%$. The condition of wives who use contraceptives is $24 \%$, wives who often use contraceptives are $13 \%$, while wives who routinely check the use of contraceptives are $16 \%$.

Keywords : Reproductive, Fertility, Millenial

Intan Cristia Ega Pratiwi, Universitas PGRI Madiun intancristia52@gmail.com

Indah Rahmadianti, Universitas PGRI Madiun indahrhmo8@gmail.com

Faliq Dzyi Nuha, Universitas PGRI Madiun faliqdziynuha@gmail.com

Wachidatul Linda Yuhanna, Universitas PGRI Madiun linda.yuhanna@unipma.ac.id 


\section{Pendahuluan}

Pengetahuan serta pemahaman kesehatan reproduksi serta fertilitas sangatlah dibutuhkan bagi generasi muda untuk mempersiapkan pernikahan mereka. Hal ini disebabkan karena kedua masalah tersebut terkait erat dengan angka kematian ibu serta masalah kesehatan yang akan ditanggung pre dan pasca melahirkan. Data SDKI tahun 2017 menunjukkan bahwa 7 persen wanita umur 15-19 tahun sudah menjadi ibu dengan detail data adalah 5 persen sudah pernah melahirkan dan 2 persen sedang hamil anak pertama (Badan Kependudukan dan Keluarga Berencana Nasional \& Kementerian Kesehatan, 2017). Hasil tersebut menggambarkan bahwa masa di usia yang seharusnya mereka menempuh pendidikan tinggi ternyata sudah disibukkan dengan aktifitas menjadi ibu dan mengasuh anak-anak yang dilahirkan. Di sisi lain kondisi tersebut juga menggambarkan bahwa generasi milenial cenderung memiliki keinginan seks aktif yang seharusnya diimbangi dengan pengetahuan terkait kesehatan reproduksi serta fertilitas.

Kesehatan Reproduksi menjadi permasalahan saat dimulainya proses perkawinan/hidup bersama terutama saat dilakukan di usia dini (remaja). Data BPS terkait tingginya angka menikah muda menjadikan tingginya kompleksitas masalah kesehatan reproduksi pada wanita. Hal ini dikarenakan menikah pada usia dini menjadikan masalah pada kesehatan reproduksi karena semakin muda umur menikah maka akan semakin panjang rentang waktu untuk bereproduksi (Mas'ud, 2013). Kesehatan Reproduksi merupakan keadaan sejahtera baik mental, fisik, social yang utuh dalam segala hal yang berkaitan dengan fungsi, peran dari sistem reproduksi baik laki-laki maupun perempuan (Purbono, 2015). Pada dasarnya pengetahuan terkait masalah reproduksi dan kesehatannya tidak hanya wajib bagi remaja putri saja. Remaja laki-laki juga perlu mengetahui serta mengerti cara hidup dengan reproduksi yang sehat. Oleh karena itu pengetahuan terkait kesehatan reproduksi antara lain pengenalan terhadap sistem, proses, serta fungsi alat reproduksi, yang dapat disampaikan secara edukatif sesuai dengan usia dan kesiapan anak dan tingkat pendidikan. Risiko penyakit reproduksi sebaiknya mulai dikenalkan dan disampaikan terutama pada remaja yang sudah beranjak dewasa, sehingga akan lebih berhatihati dan bertanggung jawan menjaganya. Pengetahuan tentang kekerasan seksual dan cara meghindarinya, sehingga dapat mengantisipasi kemungkinan kekerasana seksual yang terjadi, apa saja jenisnya dan bagaimana cara mencegah.

Perkembangan usia berpengaruh signifikan dengan perkembangan seksual serta reproduksi baik pada perempuan maupun laki-laki. Kesadaran terhadap kesehatan reproduksi bagi masing-masing orang sangat penting untuk diketahui dan dipahamkan sebagai bentuk tanggung jawab pribadi dan penghargaan terhadap diri sendiri. Remaja perlu memiliki kesadaran terhadap kesehatan reproduksi dikarenakan usia tersebut adalah saat mereka perlu membangun kebiasaan menjaga kebersihan alat reproduksinya sebagai asset penting di masa depan. Demikian juga remaja-remaja tersebut akan mempersiapkan diri memasuki fase dewasa awal dan mempersiapkan masa pernikahannya (Muchlisah, 2012). Permasalahan utama kesehatan reproduksi remaja (KRR) di indonesia adalah kurangnya informasi terkait kesehatan reproduksi, masalah pergeseran perilaku seksual remaja, pelayanan kesehatan yang buruk, serta perundang-undangan yang tidak mendukung (Irawan, 2016). 
Edukasi terkait kesehatan reproduksi sangat penting dilakukan sehingga dapat mencegah kemungkinan buruk yang membahayakan generasi milenial seperti kehamilan di usia muda, penyakit seksual, dan bahkan aborsi yang dapat berujung pada kematian. Aturan bagi warganegara dalam upaya memperhatikan kesehatan reproduksinya tertuang dalam peraturan kementrian kesehatan RI nomer 61 Tahun 2014 (Kemenkes, 2014), yang menyatakan bahwa kesehatan reproduksi merupakan hak setiap warganegara yang perlu dijamin kesehatannya. Oleh karena itu seseorang yang mengetahui kesehatan reproduksi dengan baik akan menunjukkan perilaku baik dalam hal kesadaran kemungkinan terpapar kegiatan seksual dengan resiko buruk yang ditimbulkannya seperti seks bebas, kehamilan di usia muda dan aborsi (Pratama, 2017).

Fertilitas merupakan istilah demografi yang dapat diartikan sebagai hasil reproduksi dari seorang wanita atau kelompok wanita yang dikaitkan dengan banyaknya bayi yang lahir hidup. Dengan demikian seorang perempuan yang secara biologis subur (fecund) tidak selalu melahirkan anak banyak namun dia dapat mengatur frekuensi fertilitas dengan memanfaatkan penggunaan alat-alat kontrasepsi. Angka fertilitas cenderung sulit untuk diketahui dengan pasti terutama karena satu perempuan bisa menghasilkan beberapa bayi yang lahir. Artinya kondisi yang sama tidak terjadi sebaliknya sehingga penghitungan fertilitas hanya didasarkan pada angka kelahiran bayi yang hidup saja (Mahendra, 2017).

Fertilitas merupakan kemampuan menghasilkan keturunan yang erat kaitannya dengan kesuburan. Usia subur seorang wanita pada usia 15-49 tahun, karena kemungkinan wanita melahirkan anak cukup besar. Faktor-faktor yang mempengaruhi fertilitas terdiri dari faktor sosial ekonomi, biologis, demografi dan alat kontrasepsi yang digunakan (Hanum, 2018). Faktor sosial ekonomi yang meliputi pendidikan, pekerjaan, dan pendapatan. Faktor biologis yang meliputi usia perkawinan pertama, lamanya kawin, dan waktu senggang. Faktor demografi yang meliputi struktur umur, setatus perkawinan pertama, lamanya kawin dan waktu senggang. Alat kontrasepsi yang digunakan juga mempengaruhi karena terkait dengan kondisi hormonal.

Mengetahui serta memahami kondisi fertilitas terutama di kalangan remaja menjadi isu penting untuk dibahas dari segi kesehatan dan sosial karena berhubungan dengan tingkat morbiditas serta mortalitas ibu dan anak. Kondisi ibu muda yang masih remaja terutama di bawah usia 18 tahun berpeluang mengalami masalah kesehatan diri dan bayi yang dilahirkannya (Raharja, 2014). Di sisi lain menikah serta melahirkan pada usia muda jelas mengurangi kesempatan mendapatkan pendidikan serta pekerjaan sehingga berpengaruh juga pada kualitas sumber daya manusia. Oleh karena memberikan pemahaman untuk menjadi aseptor $\mathrm{KB}$ serta menjarangkan angka kelahiran bagi perempuan yang sudah menikah merupakan faktor penting dalam rangka mempertahankan kualitas serta ketahanan rumah tangga (Sari, 2017). Tujuan dari penelitian ini adalah mengetahui tingkat pengetahuan reproduksi dan kondisi fertilitas generasi milenial di Desa Kerik Kabupaten Magetan.

\section{Metode}

Penelitian ini dilakukan pada bulan Juni 2021. Penelitian ini dilakukan di Desa Kerik, Kecamatan Takeran Kabupaten Magetan. Penelitian ini adalah penelitian kuantitatif dengan 
metode survei. Populasi dari penelitian ini sejumlah 145 orang. Sampel yang diteliti sejumlah 45 responden yang dipilih secara purposive. Sampel harus memenuhi kriteria generasi milenial (usia 23-40 tahun), sudah menikah, usia pernikahan maksimal 5 tahun, bersedia mengisi survei.

Data yang diambil adalah data pengetahuan reproduksi dan fertilitas. Instrumen data pengetahuan reproduksi terdiri dari soal sejumlah 30 soal (Mursit, 2018). Instrumen data pengetahuan fertilitas adalah kuesioner terdiri dari 20 soal (Raharja, 2014; Sari, 2017). Data yang diperoleh dianalisis secara deskriptif kuantitatif dengan melihat presentase hasil jawaban dari responden.

\section{Hasil dan Pembahasan}

Penelitian ini secara umum akan memotret data pengetahuan reproduksi dan kondisi fertilitas masyarakat desa Kerik usia produktif pada generasi milenial. Data ini penting untuk pemetaan dan database kader BKKBN untuk pengembangan DM menuju keluarga yang berkualitas. Data hasil survey tingkat pengetahuan reproduksi disajikan pada gambar 1. Berdasarkan data hasil survei yang telah dilaksanakan menunjukkan bahwa tingkat pengetahuan reproduksi dari generasi milenial di Desa Kerik sejumlah 31 responden dengan kriteria sangat baik sebanyak 68,90\%. Sejumlah 14 responden memiliki pengetahuan reproduksi dengan kriteria baik sebanyak 31,10\%. Perbedaan hasil jawaban responden disebabkan oleh beberapa faktor diantaranya sikap responden dalam mencari tahu tentang kesehatan reproduksi, ataupun faktor lain seperti media, teman, orang tua, pendidikan yang diperoleh ataupun faktor usia dari generasi milenial tersebut (Senja, 2020). Kesehatan reproduksi serta hubungannya dengan aktivitas remaja dalam menjaga kesehatan reproduksi. Aktivitas generasi milenial dalam menjaga kesehatan reproduksi, dipengaruhi oleh faktor predisposisi (pengetahuan dan sikap), faktor pendukung (pendidikan kesehatan reproduksi), dan faktor penguat (aktifitas petugas kesehatan dan tokoh ) (Wijaya, 2014).

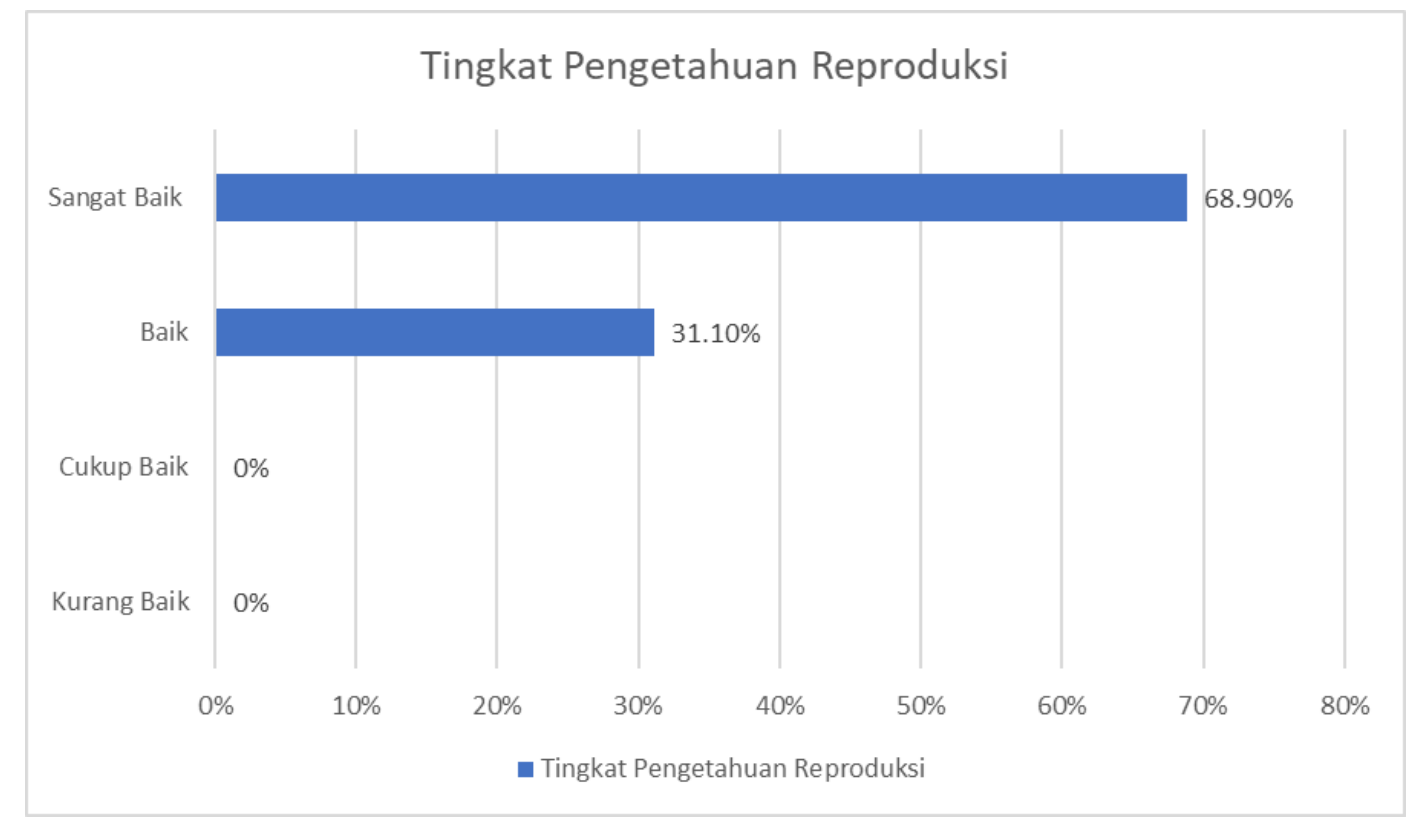

Gambar 1. Tingkat Pengetahuan Reproduksi Generasi Milenial Desa Kerik 
Generasi milenial laki-laki yang memiliki kriteria sangat baik sebanyak 16 orang sedangkan kriteria baik 6 orang, adapun generasi milenial perempuan yang memiliki kriteria sangat baik 15 orang, sedangkan kriteria baik 8 orang. Perbedaan pengetahuan reproduksi dari generasi milenial di desa kerik pada generasi milenial laki-laki dan perempuan memiliki perbedaan, sehingga jenis kelamin dapat dikatakan merupakan salah satu faktor yang dapat mempengaruhi pengetahuan reproduksi generasi milenial di desa kerik (Ernawati, 2018). Pengetahuan generasi melenial umur 15-24 tahun tingkat kesehatan reproduksi masih rendah, $21 \%$ remaja perempuan tidak mengetahui sama sekali perubahan yang terjadi pada generasi milenial laki-laki saat pubertas. Pengetahuan remaja tentang masa subur relative masih rendah (Buzarudina, 2013).

Kondisi fertilitas masyarakat sangat berhubungan dengan tingkat kesehatan. Kondisi fertilitas masyarakat Desa kerik disajikan pada tabel 1. Data tabel 1 menunjukan hasil survei kondisi fertilitas yang meliputi status pernikahan, kondisi mengandung, kondisi melahirkan, usia melahirkan pertama, kondisi anak yang dilahirkan, keinginan jumlah anak, dan status pemakaian konstrasepsi.

Status Pernikahan, dari data yang diperoleh 45 responden sudah menikah dan tidak pernah bercerai. Di desa kerik terdapat 33\% generasi milenial yang menikah usia di bawah 20 tahun sedangkan $67 \%$ generasi milenial menikah usia di atas 20 tahun. Rata-rata umur masyarakat saat menikah pertama kali serta lamanya seseorang dalam status perkawinan akan mempengaruhi tinggi rendahnya fertilitas (Hanum, 2018).

Kondisi mengandung, perempuan di desa kerik yang sudah pernah mengandung sebanyak $71 \%$, sedangkan $29 \%$ perempuan di desa kerik belum pernah mengandung. Selain itu angka keguguran di desa ini adalah 4\% sedangkan 96\% bayinya selamat. Kondisi kesehatan ibu hamil sangat penting karena sangat berpengaruh terhadap status kesehatan bayi yang di lahirkannya. Gaya hidup yang tidak sehat juga mengakibatkan bayi lahir dengan prematur, bayi berat lahir rendah, dan menyebabkan resiko kematian pada bayi yang dilahirkan (Sutiyah, 2018).

Kondisi melahirkan istri di desa kerik di peroleh data bahwa kebanyakan perempuan di desa kerik melahirkan bayinya secara sesar sebanyak $49 \%$ dan yang melahirkan dengan cara normal tergolong lebih sedikit. Akan tetapi setelah masa persalinan $67 \%$ perempuan merasa lebih lebih sehat setelah melahirkan. Adanya berbagai permasalahan kondisi kesehatan ibu hamil atau melahirkan yang masih kekurangan vitamin atau mempunyai status gizi yang rendah membutuhkan upaya untuk meningkatkan status tersebut dengan pemenuhan gizi ibu hamil dan melahirkan namun juga dengan upaya-upaya lain yang sifatnya menguatkan kondisi psikologisnya (Sudirman, 2019).

Usia melahirkan pertama di bawah usia kurang dari 20 tahun sebanyak 16\%, melahirkan di usia 20-25 tahun sebanyak 47\%, sedangkan melahirkan anak pertama di usia lebih dari 25 tahun sebanyak 13\%. Hal ini sesuai dengan (Mubina, 2021) masyarakat generasi milenial yang memilih untuk menikah muda tanpa persiapan yang matang sebelumnya, sehingga dapat menjadikan angka fertilitas (angka kelahiran) pada masyarakat selalu meningkat setiap tahunnya. 
Kondisi anak yang dilahirkan dengan selamat dan sehat sebanyak $100 \%$, sedangkan pada saat bayi dilahirkan tidak ada angka kematian bayi setelah dilahirkan. istri mengandung lagi setelah melahirkan anak pertama sebanyak 9\%. Pengaturan jarak antar anak sangat penting karena dapat berdampak pada kesehatan ibu dan juga anaknya. Kurangnya partisipasi dan penggunaan alat kontrasepsi dan belum memahami pentingnya pengetahuan tentang mengatur jarak kelahiran hal ini memperlihatkan bahwa kurang sadar akan pentingnya hal tersebut (Haribaik, 2017).

Keinginan jumlah anak, di desa kerik yang memiliki satu anak sebanyak 51\%, yang memiliki lebih dari satu anak sebanyak $18 \%$, sedangkan yang berencana memiliki anak lagi sebanyak $47 \%$. Teori pilihan rasional mengacu terhadap tindakan seseorang yang mengarah kepada suatu tujuan serta tindakan tersebut di tentukan oleh nilai atau pilihan. Dengan demikian ketika sebuah keluarga memutuskan untuk mempunyai banyak atau sedikitnya anak tentu berdasarkan pilihan rasional masing-masing keluarga tersebut. Walaupun tentu saja, masing-masing keluarga mempunyai presepsi berbeda, sehingga keputusan untuk mempunyai berapa anak, tentu saja akan berbeda (Handayani, 2019).

Tabel 1. Data kondisi fertilitas masyarakat Desa Kerik

\begin{tabular}{|c|c|c|c|c|c|c|}
\hline \multirow{2}{*}{ No. } & \multirow{2}{*}{ Aspek } & \multirow{2}{*}{ Pertanyaan } & \multicolumn{2}{|c|}{ Jawaban Iya } & \multicolumn{2}{|c|}{ Jawaban Tidak } \\
\hline & & & Jumlah & $\%$ & Jumlah & $\%$ \\
\hline 1. & Status & Apakah anda sudah menikah? & 45 & $100 \%$ & 0 & $0 \%$ \\
\hline 2. & Pernikahan & Apakah anda pernah bercerai? & 0 & $0 \%$ & 45 & $100 \%$ \\
\hline 3. & & $\begin{array}{l}\text { Anda menikah pertama kali di } \\
\text { usia kurang dari } 20 \text { tahun? }\end{array}$ & 15 & $33 \%$ & 30 & $67 \%$ \\
\hline 4. & $\begin{array}{l}\text { Kondisi } \\
\text { Mengandung }\end{array}$ & $\begin{array}{l}\text { Apakah anda/ istri pernah } \\
\text { mengandung? }\end{array}$ & 31 & $71 \%$ & 14 & $29 \%$ \\
\hline 5. & & $\begin{array}{l}\text { Apakah anda/istri pernah } \\
\text { mengalami keguguran }\end{array}$ & 2 & $4 \%$ & 43 & $96 \%$ \\
\hline 6. & $\begin{array}{l}\text { Kondisi } \\
\text { Melahirkan }\end{array}$ & $\begin{array}{l}\text { Apakah anda/istri melahirkan } \\
\text { secara normal? }\end{array}$ & 22 & $49 \%$ & 23 & $51 \%$ \\
\hline 7. & & $\begin{array}{l}\text { Apakah anda/ istri melahirkan } \\
\text { secara sesar? }\end{array}$ & 12 & $27 \%$ & 33 & $73 \%$ \\
\hline 8. & & $\begin{array}{l}\text { Apakah anda/ istri merasa } \\
\text { sehat setelah melahirkan? }\end{array}$ & 30 & $67 \%$ & 15 & $33 \%$ \\
\hline 9. & $\begin{array}{l}\text { Usia } \\
\text { melahirkan }\end{array}$ & $\begin{array}{l}\text { Anda memiliki anak pertama di } \\
\text { usia kurang dari } 20 \text { tahun? }\end{array}$ & 7 & $16 \%$ & 38 & $84 \%$ \\
\hline 10. & pertama & $\begin{array}{l}\text { Anda memiliki anak pertama } \\
\text { antara usia } 20-25 \text { tahun? }\end{array}$ & 21 & $47 \%$ & 24 & $53 \%$ \\
\hline 11. & & $\begin{array}{l}\text { Apakah anda/ istri melahirkan } \\
\text { anak pertama di usia > } 25 \\
\text { tahun? }\end{array}$ & 6 & $13 \%$ & 39 & $64 \%$ \\
\hline 12. & $\begin{array}{l}\text { Kondisi anak } \\
\text { yang } \\
\text { dilahirkan }\end{array}$ & $\begin{array}{l}\text { Apakah kondisi anak pertama } \\
\text { anda sehat dan selamat saat } \\
\text { dilahirkan? }\end{array}$ & 45 & $100 \%$ & 0 & $0 \%$ \\
\hline 13. & & $\begin{array}{l}\text { Apakah kondisi anak pertama } \\
\text { meninggal setelah dilahirkan? }\end{array}$ & 0 & $0 \%$ & 45 & $100 \%$ \\
\hline 14. & & Apakah anda/ istri langsung & 4 & $9 \%$ & 41 & $91 \%$ \\
\hline
\end{tabular}


mengandung lagi di tahun

berikutnya setelah melahirkan?

\begin{tabular}{|c|c|c|c|c|c|c|}
\hline 15. & $\begin{array}{l}\text { Keinginan } \\
\text { jumlah anak }\end{array}$ & $\begin{array}{ll}\text { Apakah anda sekarang } \\
\text { memiliki satu anak? }\end{array}$ & 23 & $51 \%$ & 22 & $49 \%$ \\
\hline 16. & & $\begin{array}{l}\text { Apakah anda sudah memiliki } \\
\text { lebih dari satu anak? }\end{array}$ & 8 & $18 \%$ & 37 & $82 \%$ \\
\hline 17. & & $\begin{array}{l}\text { Apakah anda berencana } \\
\text { memiliki anak lagi? }\end{array}$ & 21 & $47 \%$ & 24 & $53 \%$ \\
\hline 18. & $\begin{array}{l}\text { Status } \\
\text { pemakaian } \\
\text { kontrasepsi }\end{array}$ & $\begin{array}{lr}\text { Apakah anda/ istri } \\
\text { mempergunakan } & \text { alat } \\
\text { kontrasepsi? } & \end{array}$ & 11 & $24 \%$ & 34 & $76 \%$ \\
\hline 19. & & $\begin{array}{l}\text { Apakah anda/ istri rutin } \\
\text { menggunakan alat kontrasepsi? }\end{array}$ & 6 & $13 \%$ & 39 & $87 \%$ \\
\hline 20. & & $\begin{array}{l}\text { Apakah anda/ istri rutin } \\
\text { memeriksakan pemakaian alat } \\
\text { kontrasepsi anda? }\end{array}$ & 7 & $16 \%$ & 38 & $84 \%$ \\
\hline
\end{tabular}

Status pemakaian kontrasepsi, istri yang menggunakan alat kontrasepsi sebanyak $24 \%$, istri yang sering menggunakan alat kontrasepsi sebanyak $13 \%$, sedangkan istri yang rutin memeriksakan pemakaian alat kontrasepsi sebanyak 16\%. Terdapat usaha yang cukup penting untuk meningkatkan sumber pelayanan kontrasepsi melalui pemerintah dan swasta. Media informasi layanan KB menjadi konfonding untuk fertilitas, dimana hal tersebut mempengaruhi metode kontrasepsi yang digunakan oleh wanita (Sari, 2017).

\section{Simpulan}

Tingkat pengetahuan reproduksi dari generasi milenial di Desa Kerik menunjukkan bahwa 31 responden dengan kriteria sangat baik sebanyak 68,90\% dan 14 responden yang dengan kriteria baik sebanyak $31,10 \%$. Kondisi fertilitas generasi milenial di Desa Kerik yang meliputi status pernikahan, kondisi mengandung, kondisi melahirkan, usia melahirkan pertama, kondisi anak yang dilahirkan, keinginan jumlah anak, dan status pemakaian konstrasepsi secara umum dalam kondisi sangat baik.

\section{Ucapan Terima Kasih}

Penulis menyampaikan terima kasih kepada Belmawa Kemdikbudristek yang telah mendukung kegiatan ini melalui pendaaan PKM-RSH. Penulis juga menyampaiakn terimakasih kepada Universitas PGRI Madiun dan masyarakat Desa Kerik Kecamatan Takeran Kabupaten Magetan sebagai mitra dalam kegiatan ini.

\section{Daftar Rujukan}

Badan Kependudukan dan Keluarga Berencana Nasional, B. P. S., \& Kementerian Kesehatan, U. (2017). Survei Demografi Kesehatan Indonesia 2017. In Badan Pusat Statistik.

Buzarudina, F. (2013). Efektivitas Penyuluhan Kesehatan Reproduksi Remaja Terhadap Tingkat Pengetahuan Siswa Sman 6 Kecamatan Pontianak Timur. Jurnal Mahasiswa $\begin{array}{lllll}\text { PSPD } \quad \text { UK } & \text { Universitas }\end{array}$ http://jurnal.untan.ac.id/index.php/jfk/article/view/3783 
Ernawati, H. (2018). Pengetahuan Kesehatan Reproduksi Remaja Di Daerah Pedesaan. Indonesian Journal for Health Sciences, 2(1), 58. https:// doi.org/10.24269/ijhs.v2i1.820

Handayani, A., \& Najib. (2019). Keinginan Memiliki Anak Berdasarkan Teori Pilihan Rasional (Analisis Data Sdki Tahun 2017). EMPATI-Jurnal Bimbingan Dan Konseling, 6(2), 31-40. https:// doi.org/10.26877/empati.v6i2.4277

Hanum, N., \& Andiny, P. (2018). Pengaruh Tingkat Pendidikan, Usia Perkawinan Pertama dan Kematian Bayi terhadap Fertilitas di Kabupaten Aceh Timur. Jurnal Samudra Ekonomi Dan Bisnis, 9(2), 160-170. https://doi.org/10.33059/jseb.v9i2.764

Haribaik, M. A. S., Astawa, I. B. M., \& Sutarjo. (2017). Studi Komparatif Tentang Fertilitas Migran Dan Nonmigran Di Kota Singaraja. Jurnal Pendidikan Geografi Undiksha, 5(1). https:// doi.org/10.23887/jjpg.v5i1.20656

Irawan, E. (2016). Gambaran Pengetahuan Remaja Tentang Kesehatan Reproduksi Di Desa Kertajaya. Jurnal Keperawatan BSI, 4(1), 26-31. https://ejournal.bsi.ac.id/ejurnal/index.php/jk/article/view/313/304

Kemenkes. (2014). Peraturan Pemerintah No. 61 Tahun 2014 tentang Kesehatan Reproduksi. In Peraturan Pemerintah (p. 55). http://kesga.kemkes.go.id/images/pedoman/PP No. 61 Th 2014 ttg Kesehatan Reproduksi.pdf

Mahendra, A. (2017). Analisis Faktor-faktor yang Mempengaruhi Fertilitas di Indonesia. Jurnal Riset Akuntansi \& Keuangan, 3(2), 223-242.

Mas'ud, T., Saptarini, I., Amaliah, N., \& Rizkianti, A. (2013). Kesehatan Reproduksi (Reproductive Health). September 2015.

Mubina, N. (2021). Edukasi Pernikahan Dan Fertilitas Pada Penduduk Desa Mulya Sejati Kecamatan Ciampel Kabupaten Karawang. Paper Knowledge . Toward a Media History of Documents, 1687-1696.

Muchlisah. (2012). Perbedaan Usia Wanita Ketika Menikah (Remaja dan Dewasa) dalam Hubungannya dengan Penyesuaian Pernikahan di Kota Makassar. Jurnal Psikologi UIN Sultan Syarif Kasim Riau, 8(Desember), 105-110.

Pratama, T. R., Nugroho, D., \& Dharminto. (2017). Hubungan Pengetahuan Kesehatan Reproduksi Dan Pendidikan Ibu Dengan Risiko Wanita Pus Muda Di Desa Candigaron Kecamatan Sumowono Kabupaten Semarang Tahun 2017. Jurnal Kesehatan Masyarakat (e-Journal), 5(3), 66-76.

Purbono, I. A., Prabawati, M., \& Tarma. (2015). Tingkat Pengetahuan Remaja Tentang Kesehatan Reproduksi. Jurnal FamilyEdu, 6(2252-6870), 55-62.

Raharja, M. B. (2014). Fertilitas Remaja di Indonesia. Kesmas: National Public Health Journal, 9(1), 6. https://doi.org/10.21109/ kesmas.v9i1.449

Sari, N. (2017). Determinan Fertilitas melalui Pendekatan Total Fertility Rate (TFR) di Indonesia: Analisis Data Survei Demografi Kesehatan Indonesia (SDKI) Tahun 2007. Jurnal Dunia Kesmas Volume, 6(2), 55-62.

Senja, A. O., Widiastuti, Y. P., \& Istioningsih. (2020). Tingkat Pengetahuan Remaja Tentang Kesehatan Reproduksi. FamilyEdu: Jurnal Pendidikan Kesejahteraan Keluarga, 1(2), 85-92.

Sudirman, Puspitawati, H., \& Muflikhati, I. (2019). Peran Suami dalam Menentukan 
Kesejahteraan Subjektif Istri pada Saat Hamil dan Melahirkan. Jurnal Ilmu Keluarga Dan Konsumen, 12(1), 26-37. https:/ / doi.org/10.24156/jikk.2019.12.1.26

Sutiyah. (2018). Faktor-Faktor yang mempengaruhi Kepatuhan Ibu Hamil Terhadap Konsumsi Tablet Fe (Besi) Selama Kehamilan Di Puskesmas Rantau Selamat Kab.Aceh Timur Tahun 2018. 1(1), 32-41.

Wijaya, M. K., Agustini, N. N. M., \& MS, G. D. T. (2014). Pengetahuan, Sikap Dan Aktivitas Remaja Sma Dalam Kesehatan Reproduksi Di Kecamatan Buleleng. KESMAS - Jurnal Kesehatan Masyarakat, 10(1), 33-42. https:// doi.org/10.15294/kemas.v10i1.3068 